\title{
Application of Taguchi Methods for the Optimization of Factors Affecting Engine Performance and Emission of Exhaust Gas Recirculation in Steam-injected Diesel Engines
}

\author{
Görkem Kökkülünk, Adnan Parlak, Eyup Bağci, Zafer Aydin
}

Yildiz Technical University, Naval Arhitecture and Maritime Faculty, Marine Engineering Department, Istanbul, Turkey gorkemk@yildiz.edu.tr, aparlak@yildiz.edu.tr, eyupbagci@yildiz.edu.tr, zaydin@yildiz.edu.tr

\begin{abstract}
In this study, optimal engine performance and pollutant emission conditions are investigated by using Taguchi Design Methods. Orthogonal arrays of Taguchi, the signalto-noise $(S / N)$ ratio and the analysis of variance (ANOVA) were employed to find the optimal levels and to analyze the effect of the operation conditions on performance and emission values. The parameters and their levels are engine speeds at 1200, 1600, 2000 and 2400 rpm, steam ratios of 0, 10, 20 and 30\% and EGR ratios of 0, 10, 20 and 30\%. Confirmation tests with the optimal levels of engine parameters were carried out in order to illustrate the effectiveness of the Taguchi optimization method. While steam and EGR ratios are found effective on emission parameters, significance levels for these parameters have been found low for effective power and torque. It was thus shown that the Taguchi method is suitable to solve the problems of performance and emissions for diesel engines.
\end{abstract}

Keywords: Taguchi Method; Diesel Engine; Pollutant Emissions; EGR; Steam

\section{Introduction}

With the growing awareness of environmental hazards, one of the most stringent problems that engineers and engine designers have encountered, in the process of diesel engine development, is the control and reduction of pollutant emissions to acceptable levels, as limited by relevant regulations. The emission rights applying to the relevant period are distributed amongst the actors of this market, keeping in mind that the permitted emission level should be gradually decreased from period to period by each actor [1]. Thus, ongoing developments in diesel emission control technologies are required to meet future emission regulations. 
There are various methods for controlling NOx emissions in the open literature. Nowadays, the topics touching on water injection have become widely used methods to reduce NOx emissions [2-5]. Water can be supplied to the engine as a direct injection, water/fuel emulsification [6], hot water fumigation and steam injection. Alahmer et al. investigated the effect of emulsified diesel fuel and found that while improving NOx emissions, specific fuel consumption (SFC) increases [7]. Tauzi et al. analyzed the water injection into inlet manifold and observed that NOx emissions reduce significantly while increasing $\mathrm{CO}$ emissions with the raise of dilution ratio and SFC [8]. Ishida et al. investigated port water injection (fumigation) into diesel engine and observed that NOx emissions reduce about $50 \%$ [9]. Parlak et al. studied water injection in the form of steam phase into intake manifold and revealed that NOx emissions and SFC reduce effective power and torque increase with electronically controlled steam injection system [10].

EGR is another method for NOx reduction [11-15]. Haşimoğlu et al. examined the effects of EGR on diesel engine and found that although NOx emissions reduced considerably, smoke emissions and SFC deteriorated [16]. Mani et al. investigated the effect of cooled EGR using $100 \%$ waste plastic oil on diesel engine and observed that NOx, $\mathrm{CO}, \mathrm{CO}_{2}$ and smoke emissions decrease with the increase of EGR rate [17].

Although the NOx reduction rate with steam injection is reached up to $33 \%$ at full load condition, NOx can be decreased further by using EGR+steam injection combination. Kökkülünk [18] studied the effects of steam injected diesel engine with EGR on performance and emission parameters. However, there is a need to optimize the parameters considering engine performance and pollutant emissions. In this study, Taguchi methods are used in optimization of the factors affecting engine performance and emissions of EGR application on steam-injected diesel engine. In the experimental design; torque, effective power, SFC and emissions (NOx, $\mathrm{CO}, \mathrm{CO}_{2}$ and $\mathrm{HC}$ ) are chosen as parameters and engine speed, EGR and steam ratio as factors. The conditions which maximize the torque and effective power and minimize the SFC and emissions were investigated.

\section{Materials and Methods}

\subsection{Experimental Details}

The experiments were carried out with a single cylinder, naturally aspirated, fourstroke Diesel engine. The engine specifications and experimental set-up are shown in Table 1 and Figure 1, respectively [19, 20]. 
Table 1

Engine specifications

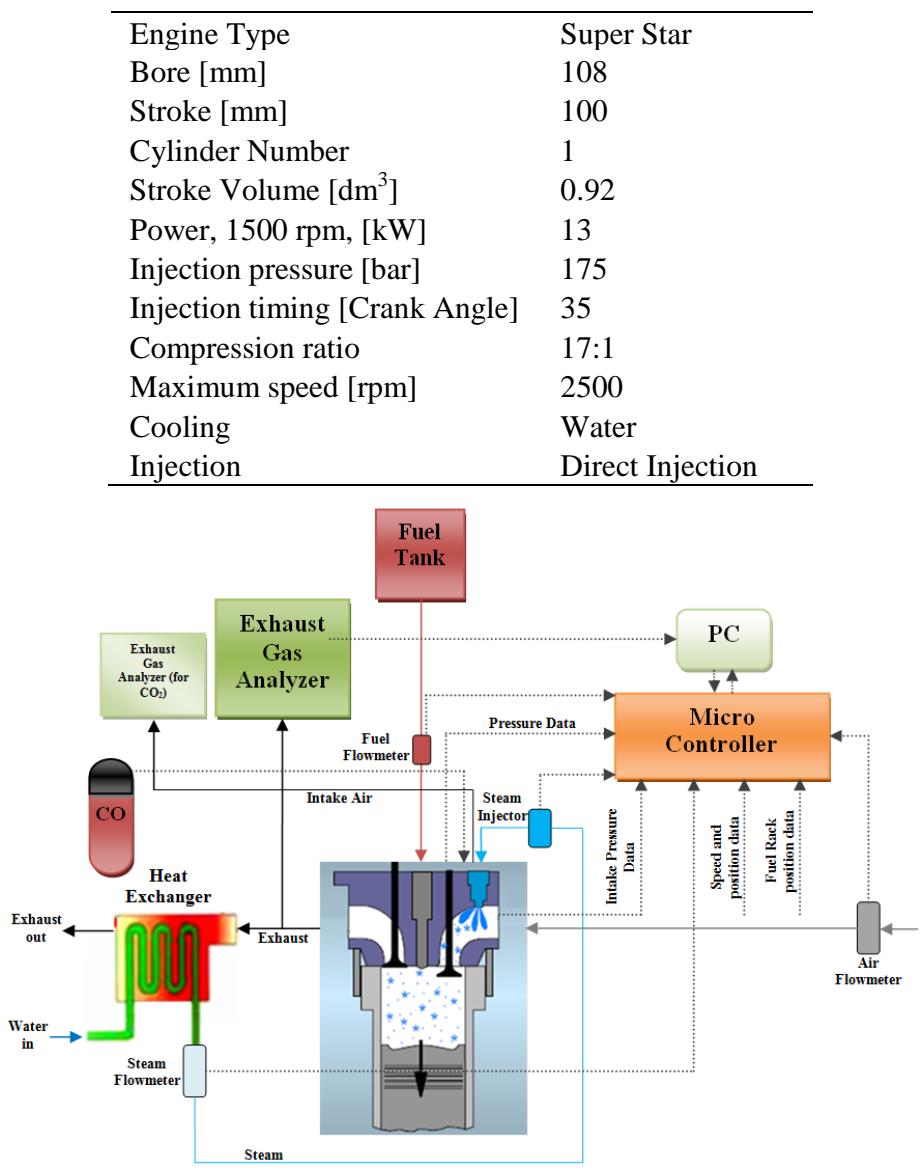

Figure 1

Experimental set-up

In order to measure brake torque, the engine is coupled with a hydraulic type dynamometer of $50 \mathrm{~kW}$ absorbing capacity using an "S" type load cell with the precision of $0.1 \mathrm{~N}$. MRU Spectra $1600 \mathrm{~L}$ type and Bilsa Mod gas analyzers were used so as to measure exhaust gases $[19,20]$.

99\% purity Linde Gas brand $\mathrm{CO}_{2}$ gas was used for EGR application so as to the most compound in exhaust gases and to calibrate EGR ratio. Method of Needham et al. [21] was used in order to determine the amount of $\mathrm{CO}_{2}$ gas. EGR percentage is:

$\operatorname{EGR}(\%)=\frac{\mathrm{CO}_{2 \text { (intake_manifold) }}-\mathrm{CO}_{2 \text { (surroundings) }}}{\mathrm{CO}_{2 \text { (exhaust_manifold) }}} \times 100$ 
Where $\mathrm{CO}_{2 \text { (surroundings) }}$ is the reference $\mathrm{CO}_{2}$ percentage in surroundings. In this study, this value was neglected owing to being $0.03 \%$ in the literature [22]. EGR ratios were determined with a volume ratio of $\mathrm{CO}_{2}$ value.

Experiments were done at the variable speeds 1200, 1600, 2000, and $2400 \mathrm{rpm}$ at full load conditions. In the experiments, 0, 10, 20 and 30\% steam and EGR ratios were carried out. The experiments were repeated for each steam and EGR ratio while performance and emission values were compared with those of a standard diesel.

\subsection{Taguchi Design Method}

In the literature, various studies have been conducted for optimizing parameters with Taguchi Design Method. Among them, Saravanan et al. investigated the effects of EGR rate, fuel injection timing and pressure in controlling NOx emission of diesel engine and experiments were designed as per Taguchi's L9 orthogonal array [23]. Ganapathy et al. analyzed thermodynamic model of Jatropha biodiesel fuelled engine by means of Taguchi method to assess the optimum engine design and operating parameters [24]. Parlak et al. studied the factors affecting emissions of a diesel engine fuelled tobacco oil seed methyl ester with Taguchi approach [25]. Win et al. investigated the effects of static injection timing, nozzle/valve opening pressure, nozzle tip protrusion, number of holes, plunger diameter, load torque, nozzle hole diameter, and engine speed on engine noise, combustion noise, smoke level, fuel economy, and exhaust emissions of a diesel engine [26]. Sivaramakrishnan et al. used Taguchi methods to optimize the diesel engine in regard to brake power, fuel economy and emissions [27].

The above studies, conducted by researchers, show that Taguchi methods provides effective solutions for investigating the effect of parameters on the performance and emissions of diesel engine. In the present study, experiments were designed to apply the Taguchi's methods to establish the effects of four (4) engine speed, steam and EGR ratios for the purpose of determining optimal conditions of performance and exhaust emissions. Three design factors and their levels are given in Table 2 .

Table 2

Design factors and levels

\begin{tabular}{cccccc}
\hline Symbols & Factors & Level 1 & Level 2 & Level 3 & Level 4 \\
\hline A & Engine Speed (rpm) & 1200 & 1600 & 2000 & 2400 \\
B & Steam Ratio (\%) & 0 & 10 & 20 & 30 \\
C & EGR Ratio (\%) & 0 & 10 & 20 & 30 \\
\hline
\end{tabular}

In Taguchi methods, the signal-noise $(\mathrm{S} / \mathrm{N})$ ratio is used to represent a performance characteristic and there are three types of $\mathrm{S} / \mathrm{N}$ ratios; the lower-the better, the higher-the better and the more nominal-the better [27]. In this study, the lower-the better was used for SFC, $\mathrm{NOx}, \mathrm{CO}, \mathrm{CO}_{2}$ and $\mathrm{HC}$ emissions and the 
higher-the better for torque and effective power. These three different $\mathrm{S} / \mathrm{N}$ ratios are expressed in Table 3, where $\mathrm{n}$ and $\mathrm{Y}$ is the number of repeated experiment and the measured value of the response variable, respectively.

Table 3

S/N Ratios Formulations

\begin{tabular}{ll}
\hline The lower-The better & $\mathrm{S} / \mathrm{N}=-10 \log \left(\sum \mathrm{Y}^{2} / \mathrm{n}\right)$ \\
The higher-The better & $\mathrm{S} / \mathrm{N}=-10 \log \left(\sum\left(1 / \mathrm{Y}^{2}\right) / \mathrm{n}\right)$ \\
The more nominal-The better & $\mathrm{S} / \mathrm{N}=10 \log \left(\sum \overline{\mathrm{Y}}^{2} / \mathrm{S}^{2}\right)$ \\
\hline
\end{tabular}

The orthogonal array mixed $\mathrm{L}_{16}$ selected as shown in Table 4 , which has 16 rows corresponding to the number of tests with all columns at four levels and the factors and the interactions are assigned to the columns [28].

Table 4

Experimental Plan of $\mathrm{L}_{16}$

\begin{tabular}{ccccc}
\hline \multirow{2}{*}{$\begin{array}{c}\text { Experiments } \\
\text { No. }\end{array}$} & Designation & \multicolumn{3}{c}{ Factors } \\
\cline { 3 - 5 } & & $(\mathrm{A})$ & $(\mathrm{B})$ & $(\mathrm{C})$ \\
\hline 1 & $\mathrm{~A}_{1} \mathrm{~B}_{1} \mathrm{C}_{1}$ & 1 & 1 & 1 \\
2 & $\mathrm{~A}_{1} \mathrm{~B}_{2} \mathrm{C}_{2}$ & 1 & 2 & 2 \\
3 & $\mathrm{~A}_{1} \mathrm{~B}_{3} \mathrm{C}_{3}$ & 1 & 3 & 3 \\
4 & $\mathrm{~A}_{1} \mathrm{~B}_{4} \mathrm{C}_{4}$ & 1 & 4 & 4 \\
5 & $\mathrm{~A}_{2} \mathrm{~B}_{1} \mathrm{C}_{2}$ & 2 & 1 & 2 \\
6 & $\mathrm{~A}_{2} \mathrm{~B}_{2} \mathrm{C}_{1}$ & 2 & 2 & 1 \\
7 & $\mathrm{~A}_{2} \mathrm{~B}_{3} \mathrm{C}_{4}$ & 2 & 3 & 4 \\
8 & $\mathrm{~A}_{2} \mathrm{~B}_{4} \mathrm{C}_{3}$ & 2 & 4 & 3 \\
9 & $\mathrm{~A}_{3} \mathrm{~B}_{1} \mathrm{C}_{3}$ & 3 & 1 & 3 \\
10 & $\mathrm{~A}_{3} \mathrm{~B}_{2} \mathrm{C}_{4}$ & 3 & 2 & 4 \\
11 & $\mathrm{~A}_{3} \mathrm{~B}_{3} \mathrm{C}_{1}$ & 3 & 3 & 1 \\
12 & $\mathrm{~A}_{3} \mathrm{~B}_{4} \mathrm{C}_{2}$ & 3 & 4 & 2 \\
13 & $\mathrm{~A}_{4} \mathrm{~B}_{1} \mathrm{C}_{4}$ & 4 & 1 & 4 \\
14 & $\mathrm{~A}_{4} \mathrm{~B}_{2} \mathrm{C}_{3}$ & 4 & 2 & 3 \\
15 & $\mathrm{~A}_{4} \mathrm{~B}_{3} \mathrm{C}_{2}$ & 4 & 3 & 2 \\
16 & $\mathrm{~A}_{4} \mathrm{~B}_{4} \mathrm{C}_{1}$ & 4 & 4 & 1 \\
\hline
\end{tabular}

\section{Results and Discussion}

The measurement of the effective performance of motor vehicles takes place by means of bench tests [29]. In this study, the optimum values of the factors (engine speed, steam and EGR ratios) affecting engine performance and emissions of EGR application on steam injected diesel engine were determined by using Taguchi methods. 
Table 5 shows the analysis of variance of experimental data. Effective power, torque, $\mathrm{SFC}, \mathrm{CO}, \mathrm{CO}_{2}, \mathrm{NOx}$ and $\mathrm{HC}$ are determined between $96.5 \%$ and $99 \%$ confidence levels.

Table 5

ANOVA results

\begin{tabular}{|c|c|c|c|c|c|}
\hline Factors & & Sum of & Degree of & Variance, & $\mathrm{F}_{\text {factor }}$ \\
\hline \multirow{5}{*}{ Torque* } & 「A] Engine & 174.49 & 3 & 58.16 & 60.49 \\
\hline & {$[\mathrm{B}]$ Steam ratio } & 0.83 & 3 & 0.28 & 0.29 \\
\hline & 「C $\rceil$ EGR ratio & 9.29 & 3 & 3.10 & 3.22 \\
\hline & Error & 5.77 & 6 & 0.96 & \\
\hline & Total & 190.39 & 15 & 12.69 & \\
\hline \multirow[b]{2}{*}{ Effective } & $\lceil\mathrm{A}\rceil$ Engine & 72.49 & 3 & 24.16 & 546.53 \\
\hline & [B] Steam ratio & 0.08 & 3 & 0.03 & 0.59 \\
\hline \multirow{2}{*}{ Power*** } & {$[\mathrm{C}\rceil \mathrm{EGR}$ ratio } & 0.39 & 3 & 0.13 & 2.92 \\
\hline & Error & 0.27 & 6 & 0.05 & \\
\hline \multirow{6}{*}{$\mathrm{SFC} * * *$} & Total & 73.23 & 15 & 4.88 & \\
\hline & 「A] Engine & 6390.38 & 3 & 2130.13 & 288.96 \\
\hline & [B] Steam ratio & 258.37 & 3 & 86.12 & 11.68 \\
\hline & $\lceil\mathrm{C}\rceil \mathrm{EGR}$ ratio & 1156.86 & 3 & 385.62 & 52.31 \\
\hline & Error & 44.23 & 6 & 7.37 & \\
\hline & Total & 7849.85 & 15 & 523.32 & \\
\hline \multirow{4}{*}{$\mathrm{NOx} * *$} & 「A] Engine & 41148 & 3 & 13716 & 14.97 \\
\hline & {$[\mathrm{B}]$ Steam ratio } & 8346 & 3 & 2782 & 3.04 \\
\hline & $\lceil\mathrm{C}\rceil$ EGR ratio & 384774 & 3 & 128258 & 139.95 \\
\hline & Error & 5499 & 6 & 916.5 & \\
\hline \multirow{5}{*}{$\mathrm{CO} * * *$} & Total & 439767 & 15 & 29317.8 & \\
\hline & 「A] Engine & 3.08 & 3 & 1.03 & 123.35 \\
\hline & {$[\mathrm{B}\rceil$ Steam ratio } & 0.09 & 3 & 0.03 & 3.94 \\
\hline & |C| EGR ratio & 2.15 & 3 & 0.72 & 86.02 \\
\hline & Error & 0.05 & 6 & 0.01 & \\
\hline \multirow{4}{*}{$\mathrm{CO}_{2} * * *$} & Total & 5.38 & 15 & 0.36 & \\
\hline & |A| Engine & 23.76 & 3 & 7.92 & 40.87 \\
\hline & |B| Steam ratio & 1.12 & 3 & 2.37 & 12.25 \\
\hline & ICI EGR ratio & 88.37 & 3 & 29.46 & 151.99 \\
\hline \multirow{6}{*}{$\mathrm{HC}^{*}$} & Error & 1.16 & 6 & 0.19 & \\
\hline & Total & 120.41 & 15 & 8.03 & \\
\hline & [B] Steam ratio & $\begin{array}{r}2059.99 \\
367.70\end{array}$ & $\begin{array}{l}5 \\
3\end{array}$ & 122.57 & $\begin{array}{r}24.01 \\
3.35\end{array}$ \\
\hline & [C] EGR ratio & 3385.70 & 3 & 1128.57 & 30.87 \\
\hline & Error & 219.39 & 6 & 36.57 & \\
\hline & Total & 6612.77 & 15 & 440.85 & \\
\hline
\end{tabular}

\subsection{Exhaust Emissions}

$\mathrm{S} / \mathrm{N}$ values of factor levels of $\mathrm{HC}, \mathrm{NOx}, \mathrm{CO}$ and $\mathrm{CO}_{2}$ emissions for engine speed, steam and EGR ratios are shown in Figure 2. As a result of study, by using the Taguchi approach, it is shown that engine speed and EGR ratios have been found to be significant in exhaust emissions. However, steam ratio has affected the exhaust emission in a different level. 
After confirmation tests were carried out, the optimum design conditions were found as $\mathrm{A}_{4} \mathrm{~B}_{4} \mathrm{C}_{1}(2400 \mathrm{rpm}, 30 \%$ steam ratio, $0 \% \mathrm{EGR})$ for $\mathrm{CO}$ and $\mathrm{A}_{1} \mathrm{~B}_{4} \mathrm{C}_{1}(1200$ $\mathrm{rpm}, 30 \%$ steam ratio, $0 \% \mathrm{EGR}$ ) for $\mathrm{CO}_{2}$. As can be seen from the Figure 2a, the effect of steam on $\mathrm{CO}_{2}$ emissions have been found meaningful for only $10 \%$ steam ratio in $99 \%$ confidence level. On the other hand, $\mathrm{CO}$ has been found significant up to $20 \%$ steam ratios tested (Figure $2 \mathrm{~b}$ ).

As can be seen from Figure 2c and Figure 2d, after confirmations test carried out in $96.5 \%$ confidence level, the optimum design parameter combination were found as $\mathrm{A}_{4} \mathrm{~B}_{3} \mathrm{C}_{1}$ (2400 rpm, 20\% steam, 0\% EGR) for $\mathrm{HC}$ emissions and $\mathrm{A}_{4} \mathrm{~B}_{2} \mathrm{C}_{4}$ (2400 rpm, 10\% steam, 30\% EGR) for NOx with the $98.5 \%$ confidence level. However, there is not a meaningful change except for the $10 \%$ steam ratio for the NOx emissions.

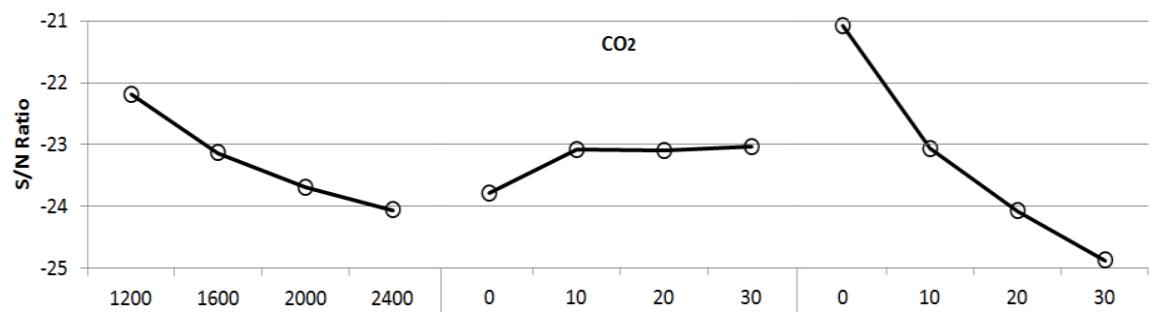

Figure 2 (a)

$\mathrm{S} / \mathrm{N}$ values of factor levels for $\mathrm{CO}_{2}$

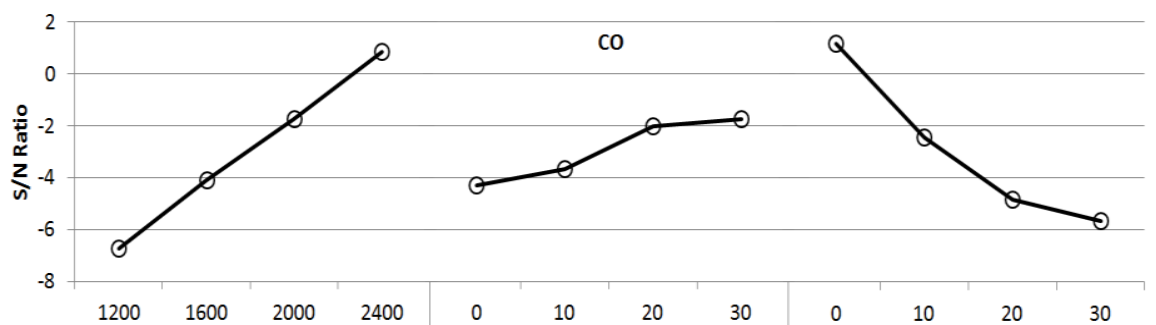

Figure 2 (b)

$\mathrm{S} / \mathrm{N}$ values of factor levels for $\mathrm{CO}$

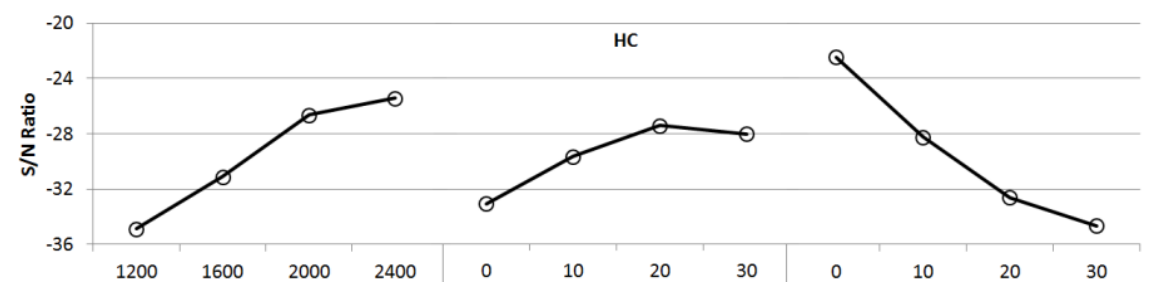

Figure 2 (c)

$\mathrm{S} / \mathrm{N}$ values of factor levels for $\mathrm{HC}$ 


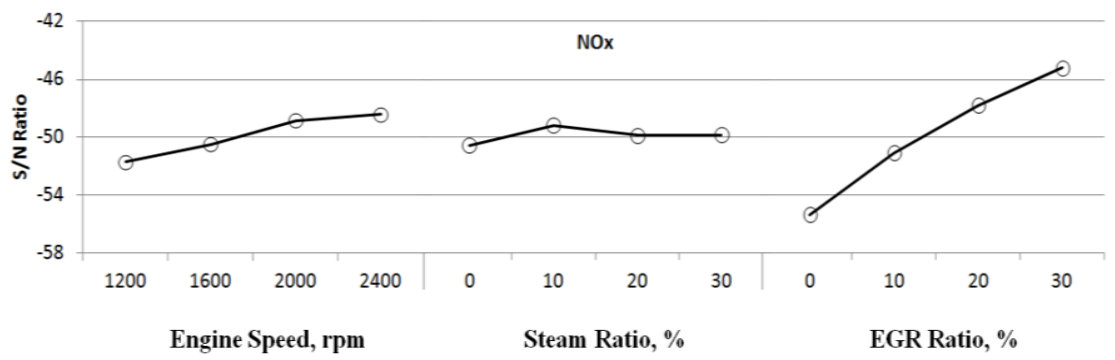

Figure 2 (d)

$\mathrm{S} / \mathrm{N}$ values of factor levels for $\mathrm{NOx}$

In conclusion, EGR has a distinct effect on NOx, in comparison to steam injection. But, when considering the negative effects of EGR on performance parameters, EGR could not be evaluated individually, as a method for reducing NOx emissions. Furthermore, when evaluating all exhaust emissions, steam injection become more significant, up to $20 \%$.

\subsection{Performance Parameters}

$\mathrm{S} / \mathrm{N}$ values of factor levels of SFC, effective power and torque for engine speed, steam and EGR ratios are shown in Figure 3. As a result of study by using the Taguchi approach, it is shown that engine speed has been found to be significant on performance parameters. However, steam and EGR ratios have affected exhaust emissions in a different level.

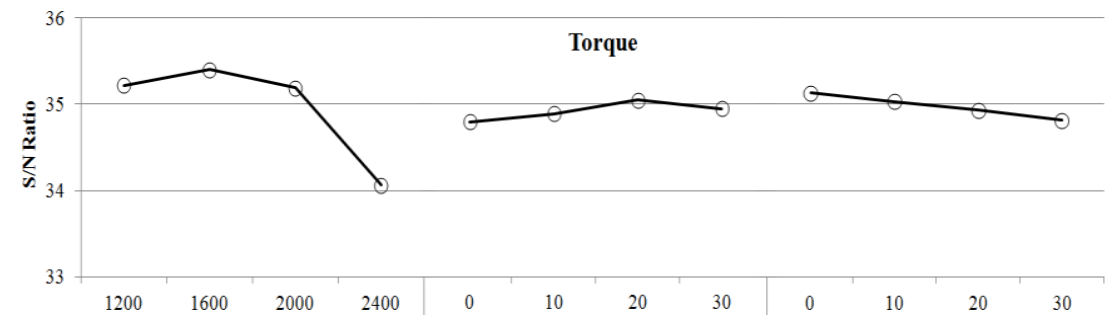

Figure 3 (a)

$\mathrm{S} / \mathrm{N}$ values of factor levels for Torque

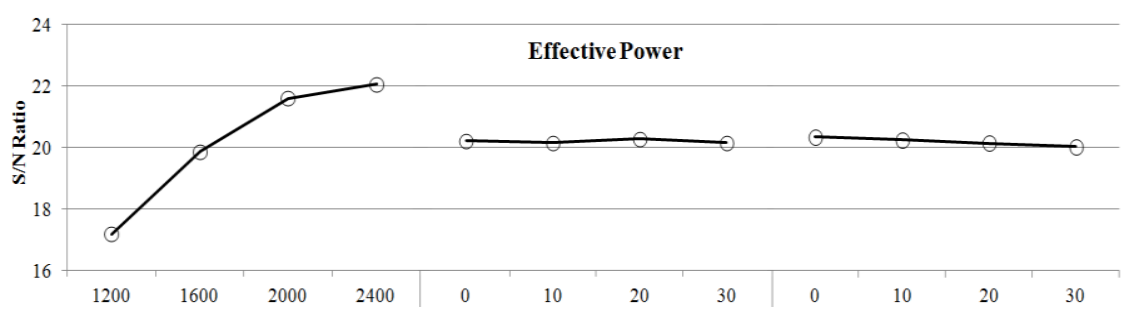

Figure 3 (b)

$\mathrm{S} / \mathrm{N}$ values of factor levels for Effective Power 


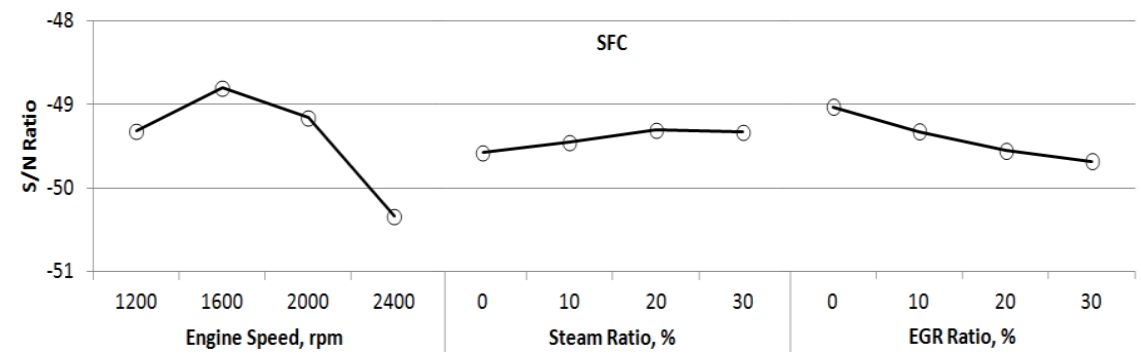

Figure 3 (c)

$\mathrm{S} / \mathrm{N}$ values of factor levels for SFC

After confirmation tests carried out at a 99\% confidence level, the optimum design parameter combination were found as $\mathrm{A}_{2} \mathrm{~B}_{3} \mathrm{C}_{1}$ (1600 rpm, 20\% steam, $0 \%$ EGR) for SFC, $\mathrm{A}_{4} \mathrm{~B}_{3} \mathrm{C}_{1}(2400 \mathrm{rpm}, 20 \%$ steam, $0 \% \mathrm{EGR}$ ) for effective power and with $96.5 \%$ confidence level, $\mathrm{A}_{2} \mathrm{~B}_{3} \mathrm{C}_{1}$ (1600 rpm, $20 \%$ steam, $\left.0 \% \mathrm{EGR}\right)$ for torque.

As can be seen from Figure $2 \mathrm{~d}, \mathrm{~A}_{4} \mathrm{~B}_{2} \mathrm{C}_{4}$ is the optimum design parameter for NOx emissions. However, the optimum steam ratio is $10 \%$ for NOx, $20 \%$ for SFC. In addition, with regards to SFC, the minimum fuel consumption is found with a $0 \%$ EGR ratio.

Moreover, the effect of steam and EGR ratios, for effective power, become meaningful comparing with standard diesel and in the case of steam injection, there is not significant change between $10 \%-30 \%$.

When considering both effective power and torque values, there is not a significant change in effective power and torque with the increase in EGR ratios. The reason of the limited reduces in effective power with the increase of EGR ratios could be derived from steam injection.

Table 6 and Table 7 show the comparison with experimental data and S/N ratios of calculated values for exhaust emissions.

Table 6

Experimental values and $\mathrm{S} / \mathrm{N}$ ratios for exhaust emissions

\begin{tabular}{lllllllll}
\hline \multirow{2}{*}{$\begin{array}{l}\text { Exp. } \\
\text { No. }\end{array}$} & \multicolumn{2}{c}{ NOx } & \multicolumn{2}{c}{$\mathrm{CO}$} & \multicolumn{2}{c}{$\mathrm{CO}_{2}$} & \multicolumn{2}{c}{$\mathrm{HC}$} \\
\cline { 2 - 10 } & $\begin{array}{l}\text { Exp. } \\
\text { val. }\end{array}$ & S/N & $\begin{array}{l}\text { Exp. } \\
\text { val. }\end{array}$ & S/N & \multicolumn{2}{c}{$\begin{array}{l}\text { Exp. } \\
\text { val. }\end{array}$} & S/N & \multicolumn{2}{l}{$\begin{array}{l}\text { Exp. } \\
\text { val. }\end{array}$} & S/N \\
\hline 1 & 697.30 & -56.87 & 1.82 & -5.23 & 10.35 & -20.29 & 37.60 & -31.50 \\
2 & 448.00 & -53.03 & 2.03 & -6.15 & 12.20 & -21.72 & 52.41 & -34.38 \\
3 & 316.14 & -49.99 & 2.29 & -7.19 & 14.20 & -23.04 & 62.86 & -35.96 \\
4 & 220.15 & -46.85 & 2.62 & -8.38 & 15.30 & -23.69 & 76.40 & -37.66 \\
5 & 426.20 & -52.59 & 1.60 & -4.08 & 15.16 & -23.61 & 41.50 & -32.36 \\
6 & 588.35 & -55.39 & 1.16 & -1.29 & 11.06 & -20.87 & 16.76 & -24.48 \\
7 & 191.12 & -45.63 & 1.99 & -6.01 & 16.55 & -24.37 & 53.05 & -34.49 \\
8 & 261.61 & -48.35 & 1.80 & -5.11 & 15.28 & -23.68 & 45.09 & -33.08 \\
9 & 228.60 & -47.18 & 1.76 & -4.91 & 17.55 & -24.88 & 50.80 & -34.11 \\
\hline
\end{tabular}




\begin{tabular}{lllllllll}
\hline 10 & 135.35 & -42.63 & 1.82 & -5.20 & 17.97 & -25.09 & 40.87 & -32.22 \\
11 & 587.62 & -55.38 & 0.64 & 3.88 & 11.73 & -21.38 & 6.68 & -16.49 \\
12 & 324.15 & -50.21 & 1.10 & -0.83 & 14.77 & -23.38 & 15.42 & -23.76 \\
13 & 192.18 & -45.67 & 1.42 & -3.08 & 20.82 & -26.36 & 51.40 & -34.21 \\
14 & 191.93 & -45.66 & 1.28 & -2.14 & 17.16 & -24.69 & 23.43 & -27.39 \\
15 & 265.23 & -48.47 & 0.87 & 1.21 & 14.95 & -23.49 & 13.53 & -22.62 \\
16 & 494.58 & -53.88 & 0.43 & 7.33 & 12.16 & -21.69 & 7.530 & -17.53 \\
\hline
\end{tabular}

Table 7

Experimental values and $\mathrm{S} / \mathrm{N}$ ratios for performance parameters

\begin{tabular}{ccccccc}
\hline \multirow{2}{*}{$\begin{array}{c}\text { Exp. } \\
\text { No }\end{array}$} & \multicolumn{2}{c}{ Torque } & \multicolumn{2}{c}{ Effective Power } & \multicolumn{2}{c}{ SFC } \\
\cline { 2 - 7 } & Exp. val. & S/N & Exp. val. & S/N & Exp. val. & S/N \\
\hline 1 & 57.64 & 35.21 & 7.24 & 17.19 & 284.64 & -49.08 \\
2 & 58.72 & 35.37 & 7.37 & 17.35 & 289.37 & -49.22 \\
3 & 57.29 & 35.16 & 7.19 & 17.14 & 296.07 & -49.42 \\
4 & 56.93 & 35.10 & 7.15 & 17.08 & 298.47 & -49.49 \\
5 & 59.79 & 35.53 & 10.01 & 20.01 & 277.56 & -48.86 \\
6 & 59.43 & 35.48 & 9.95 & 19.96 & 268.07 & -48.56 \\
7 & 58.00 & 35.26 & 9.71 & 19.74 & 279.62 & -48.93 \\
8 & 58.36 & 35.32 & 9.77 & 19.80 & 277.09 & -48.85 \\
9 & 58.01 & 35.26 & 12.14 & 21.68 & 298.00 & -49.48 \\
10 & 55.50 & 34.88 & 11.61 & 21.30 & 298.18 & -49.48 \\
11 & 58.72 & 35.37 & 12.29 & 21.79 & 270.08 & -48.62 \\
12 & 57.64 & 35.21 & 12.06 & 21.63 & 282.97 & -49.03 \\
13 & 49.77 & 33.93 & 12.50 & 21.93 & 347.62 & -50.82 \\
14 & 49.77 & 33.93 & 12.50 & 21.93 & 334.13 & -50.47 \\
15 & 49.77 & 33.93 & 12.50 & 21.93 & 322.63 & -50.17 \\
16 & 52.63 & 34.42 & 13.22 & 22.42 & 311.70 & -49.87 \\
\hline
\end{tabular}

In Taguchi methods, verification experiments should be done to determine optimum conditions and compared with experimental values. In this study, all values are within confidence levels, as a result of the verification experiments.

\section{Conclusion}

In this study, the effects of the factors (engine speed, steam and EGR ratios) on engine performance and emissions of an EGR application, with a steam injected diesel engine have been investigated using the Taguchi approach. Verification experiments were performed to compare with the Taguchi results and have a good agreement with the experimental data.

It is observed from the results, that effective power, SFC, $\mathrm{CO}$ and $\mathrm{CO}_{2}$ are determined at least $99 \%$, NOx at least $98.5 \%$ and torque, $\mathrm{HC}$ at least $96.5 \%$ confidence levels.

The optimum design parameter combinations have been found as $\mathrm{A}_{4} \mathrm{~B}_{4} \mathrm{C}_{1}(2400$ rpm, 30\% steam, 0\% EGR), $\mathrm{A}_{1} \mathrm{~B}_{4} \mathrm{C}_{1}$ (1200 rpm, 30\% steam, 0\% EGR) for $\mathrm{CO}$ and $\mathrm{CO}_{2}$, respectively and $\mathrm{A}_{4} \mathrm{~B}_{3} \mathrm{C}_{1}(2400 \mathrm{rpm}, 20 \%$ steam, $0 \% \mathrm{EGR})$ and $\mathrm{A}_{4} \mathrm{~B}_{2} \mathrm{C}_{4}$ (2400 rpm, 10\% steam, 30\% EGR) for HC and NOx emissions, respectively. 
For the performance parameters, the optimum design parameter combinations have been found as $\mathrm{A}_{2} \mathrm{~B}_{3} \mathrm{C}_{1}$ (1600 rpm, 20\% steam, 0\% EGR) for SFC, $\mathrm{A}_{4} \mathrm{~B}_{3} \mathrm{C}_{1}$ (2400 rpm, 20\% steam, 0\% EGR) for effective power and $\mathrm{A}_{2} \mathrm{~B}_{3} \mathrm{C}_{1}$ (1600 rpm, 20\% steam, $0 \%$ EGR) for torque.

The optimum steam ratio is $10 \%$ for NOx and $20 \%$ for SFC. On the contrary, with regards to SFC, the minimum fuel consumption has been found with a $0 \%$ EGR ratio. For effective power and torque values, there is not considerable change in effective power and torque with an increase in EGR ratios. The reason of a limited reduction in effective power with the increase of EGR ratios could be explained due to steam injection.

\section{Acknowledgement}

This study was supported by TUBITAK 1001 Project (project no. 111M065) and Yildiz Technical University (YTU) Scientific Research Project Coor. (BAPK) (Project no. 2011-10-02-KAP02). Thanks to TUBITAK and YTU BAPK for the financial support.

\section{References}

[1] E. Karai, M. Barany: Towards Convergence of Accounting for Emission Rights, Acta Polytechnica Hungarica, Vol. 10, No. 1, 2013, pp. 177-196

[2] F. Bedford, C. Rutland, P. Dittrich, A. Raab, F. Wirbelit: Effects of direct water injection on DI Diesel Engine Combustion, SAE paper 2000-01-2938

[3] O. Armas, R. Ballesteros, F.J. Martos, J.R. Agudelo: Characterization of Light Duty Diesel Engine Pollutant Emissions Using Water-emulsified Fuel, Fuel, Vol. 84, 2005, pp. 1011-1018

[4] F. L. Dryer: Water Addition to Practical Combustion Systems - Concepts and Applications. Symposium (International) on Combustion, Vol. 16, 1997, pp. 279-295

[5] C. Y. Lin, K. H. Wang: Diesel Engine Performance and Emission Characteristics Using Three-Phase Emulsions as Fuel, Fuel Vol. 83, 2004, pp. $537-545$

[6] G. Kökkülünk, E. Akdoğan, V. Ayhan: Prediction of Emissions and Exhaust Temperature for Direct Injection Diesel Engine with Emulsified Fuel using ANN, Turkish Journal of Electrical Engineering and Computer Sciences, Vol. 21, No:2, 2013, pp. 2141-2152

[7] A. Alahmer, J. Yamin, A. Sakhrieh, M. A. Hamdan: Engine Performance using Emulsified Diesel Fuel, Energy Conversion and Management, Vol. 51, 2010, pp. 1708-1713

[8] X. Tauzia, A. Maiboom, S. R. Shah: Experimental Study of Inlet Manifold Water Injection on Combustion and Emissions of an Automotive Direct Injection Diesel Engine, Energy, Vol. 35, 2010, pp. 3628-3639 
[9] M. Ishida, H. Ueki, D. Sakaguchi: Prediction of NOx Reduction Rate Due to Port Water Injection in a DI Diesel Engine. SAE Technical Paper, 1997, 972961

[10] A. Parlak, V. Ayhan, Y. Üst, B. Şahin, İ. Cesur, B. Boru, G. Kökkülünk: New Method to Reduce NOx Emissions of Diesel Engines: Electronically Controlled Steam Injection System, Journal of Energy Institute, Vol. 85, 2012, pp. 135-139

[11] J. W. Heffel: NOx Emission Reduction in a Hydrogen fuelled Internal Combustion Engine at $1500 \mathrm{rpm}$ using Exhaust Gas Recirculation, International Journal of Hydrogen Energy, Vol. 28, 2003, pp. 901-908

[12] M. Zheng, G. T. Reader, J. G. Hawley: Diesel Engine Exhaust Gas Recirculation-a review on advanced and novel concept. Energy Conversion and Management, Vol. 45, 2004, pp. 883-900

[13] H. E. Saleh: Experimental Study on Diesel Engine Nitrogen Oxide Reduction Running with Jojoba Methyl Ester by Exhaust Gas Recirculation, Fuel, Vol. 88, 2009, pp. 1357-1364

[14] A. Maiboom, X. Tauzia, J. F. Hetet: Experimental Study of Various Effects of Exhaust Gas Recirculation (EGR) on Combustion and Emissions of an Automotive Direct Injection Diesel Engine, Energy, Vol. 33, 2008, pp. 2234

[15] L. Shi, Y. Cui, K. Deng, H. Peng, Y. Chen: Study of Low Emission Homogeneous Charge Compression Ignition (HCCI) Engine Using Combined Internal and External Exhaust Gas Recirculation (EGR), Energy, Vol. 31, 2006, pp. 2665-2676

[16] C. Haşimoğlu, Y. İçingür, H. Öğüt: Dizel Motorlarında Egzoz Gazları Resirkülasyonunun (EGR) Motor Performansı ve Egzoz Emisyonlarına Etkisinin Deneysel Analizi, Turkish Journal of Engineering Environmental Science, Vol. 26, 2002, pp. 127-135 (in Turkish)

[17] M. Mani, G. Nagarajan, S. Sampath: An Experimental Investigation on a DI Diesel Engine using Waste Plastic Oil with Exhaust Gas Recirculation, Fuel, Vol. 89, 2010, pp. 1826-1832

[18] G. Kökkülünk, A. Parlak, V. Ayhan, İ. Cesur: Investigation of Steam Injection with Exhaust Gas Recirculation (EGR) on a Diesel Engine. $3^{\text {rd }}$ International Conference on Urban Sustainability, Cultural Sustainability, Green Development, Green Structures and Clean Cars (USCUDAR I'12), Barcelona, 2012, pp. 41-46

[19] G. Kökkülünk, G. Gonca, A. Parlak: The Effects of Design Parameters on Performance and NO Emissions of Steam-injected Diesel Engine with Exhaust Gas Recirculation, Arabian Journal for Science and Engineering, Vol. 39, No. 5, 2014, pp. 4119-4129 
[20] G. Kökkülünk, G. Gonca, V. Ayhan, İ. Cesur, A. Parlak: Theoretical and Experimental Investigation of Diesel Engine with Steam Injection System on Performance and Emission Parameters, Applied Thermal Engineering, Vol. 54, No. 1, 2013, pp. 161-170

[21] J. R. Needham, A. J. Nicol, C. H. Such: Low Emission Heavy Duty Diesel Engine for Europe. SAE Paper, 1993-620-631

[22] S. Çetinkaya: Termodinamik, Nobel Yayınları, 1999, Ankara (in Turkish)

[23] S. Saravanan, G. Nagarajan, S. Sampath: Multi Response Optimization of NOx Emission of a Stationary Diesel Engine, Fuel, Vol. 89, 2010, pp. 3235-3240

[24] T. Ganapathy, K. Murugesan, R. P. Gakkhar: Performance Optimization of Jatropha Biodiesel Engine Model using Taguchi Approach, Applied Energy, Vol. 86, 2009, pp. 2476-2486

[25] A. Parlak, H. Karabaş, İ. Özsert, V. Ayhan, İ. Cesur: Application of Taguchi's Methods to Investigate Factors Affecting Emissions of a Diesel Engine Running with Tobacco Oil Seed Methyl Ester. International Journal of Vehicle Design, Vol. 59, 2012, pp. 196-211

[26] Z. Win, R.P. Gakkhar, S. C. Jain, M. Bhattacharya: Investigation of Diesel Engine Operating and Injection System Parameters for Low Noise, Emissions, and Fuel Consumption using Taguchi Methods, Proceedings of the Institution of Mechanical Engineering Part D-Journal of Automobile Engineering, Vol. 219, 2005, pp. 1237-1251

[27] K. Sivaramakrishnan, P. Ravikumar: Performance Optimization of Karanja Biodiesel Engine using Taguchi Approach and Multiple Regressions, ARPN Journal of Engineering in Applied Science, Vol. 7, 2012, pp. 506516

[28] M. Kapsiz, M. Durat, F. Ficici: Friction and Wear Studies between Cylinder Liner and Piston Ring Pair using Taguchi Design Method, Advances in Engineering Software, Vol. 42, 2011, pp. 595-603

[29] I. Lakatos: Diagnostic Measurement for the Effective Performance of Motor Vehicles, Acta Polytechnica Hungarica, Vol. 10, No. 3, 2013, pp. 239-249 